\title{
Desain dan Implementasi Smart Wastafel Untuk Pencegahan Penularan Covid-19: Studi Kasus di Kantor Kelurahan Sorosutan Yogyakarta
}

\section{Design and Implementation of Smart Sinks for the Prevention of the Transmission of Covid- 19: A Case Study in the Sorosutan Sub-District Office in Yogyakarta}

Hasbi N. P. Wisudawan ${ }^{1 *}$, Husein Mubarok ${ }^{2}$, Aditya Sandi Nugraha ${ }^{3}$

1,2,3Program Studi Teknik Elektro, Fakultas Teknologi Industri, Universitas Islam Indonesia

\begin{abstract}
ARTICLE INFO
Article history:

DOI:

$\underline{10.30595 / p s p f s . v 1 i .131}$

Submitted:

June 27, 2021

Accepted:

July 10, 2021

Published:

Oct 31, 2021

ABSTRACT

Sorosutan is one of the villages in the Umbulharjo District with the largest population of 14,979 people based on statistical data in 2017. During the Covid-19 pandemic, the implementation of health protocols such as providing a handwashing area and mandatory wearing of masks is applied in all places, including public service places such as the Sorosutan Village Office. Socialization continues to be carried out by various parties so that residents can increase their self-discipline in every place and time, including when visiting these public places. The presence of officers or guards at each entrance is significant to remind residents who will enter. A large number of visitors will cause problems because it can cause long queues. In addition, the limited number of employees or personnel becomes a separate obstacle when it comes to preparing special personnel for controlling visitors. The smart sink is a solution in helping officers at the Sorosutan Village office remind residents to always wash their hands and wear masks when visiting the office. The temperature sensor installed in the sink can also help speed up temperature checking, which previously had to be done manually by officers. With the provision of this tool, it is hoped to increase public awareness so that the spread of Covid-19 can be reduced.
\end{abstract}

Keywords:

Covid-19, Smart sink, Sensor, Sorosutan Village, Prevention

\author{
Corresponding Author: \\ Hasbi N. P. Wisudawan \\ Program Studi Teknik Elektro, Fakultas Teknologi Industri, Universitas Islam Indonesia \\ J1 Kaliurang Km 14,5, Sleman, Yogyakarta 55584 Telp. (0274) 898444 \\ Email: hasbi.wisudawan@uii.ac.id
}

This work is licensed under a Creative Commons Attribution 4.0 International License.

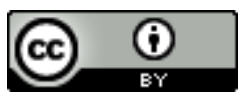

\section{PENDAHULUAN}

Sorosutan adalah salah satu nama kelurahan di antara 7 kelurahan yang terletak di kecamatan Umbulharjo, Yogyakarta. Kelurahan ini beralamat di Nitikan UH VI/236 dengan luas 1,68 Km² dan terdiri dari 18 RW dan 70 RT. Jumlah pegawai di kelurahan ini sebanyak 7 orang yang terdiri dari 4 pegawai laki-laki dan 3 pegawai perempuan. Pada tahun 2016, jumlah penduduk dalam satu kecamatan terdapat sebanyak 68.403 jiwa dengan jumlah laki-laki 33.534 jiwa dan perempuan 34.869 jiwa, jika dilihat berdasarkan kelurahan, terlihat Kelurahan Sorosutan mempunyai jumlah penduduk paling banyak yaitu 14.979 jiwa, dengan rincian laki-laki ada 7.303 jiwa dan perempuan 7.676 jiwa. Berkaitan dengan fasilitas Kesehatan, kecamatan Umbulharjo memiliki 6 rumah sakit, 2 puskesmas, 3 puskesmas pembantu serta 28 apotek (Badan Pusat Statistik Kota Yogyakarta, 2017).

Pandemi ini memberikan pelajaran berharga bagi masyarakat. Kondisi saat ini menunjukkan bahwa angka penyebaran Covid masih sangat tinggi. Di Yogyakarta tercatat 23754 warga yang terkonfirmasi positif dengan jumlah pasien dirawat sebanyak 6157, 553 meninggal dunia dan sebanyak 17044 dinyatakan sembuh (Yogyakarta Tanggap COVID-19, n.d.). Angka yang sangat tinggi ini harus menjadi perhatian bagi semua pihak baik itu instansi 
pemerintahan, swasta, pelaku usaha atau yang lainnya, termasuk masyarakat agar tidak terjadi dampat yang lebih buruk sehingga diperlukan upaya-upaya baik individu maupun kelompok yang lebih masif lagi sebagai langkah pencegahan penularan Covid-19.

Dinas Kesehatan sejak terjadinya pandemi COVID-19 (bulan Maret 2020) sudah melakukan kegiatan sosialisasi pencegahan COVID-19 menggunakan mobil keliling wilayah di Kota Yogyakarta. Pada awal pelaksanaan dilakukan oleh Dinas Kesehatan dengan mengikutsertakan Kelurahan Siaga (KESI) dan Saka Bakti Husada. Kemudian mulai bulan September 2020 sosialisasi dilaksanakan bersama Sat Pol PP Kota Yogyakarta. Ada empat pesan protokol kesehatan secara umum untuk mencegah covid-19 yang disampaikan saat sosialisasi meliputi 4 M yakni memakai masker dengan benar, mencuci tangan memakai sabun dan air mengalir atau hand saniter, menjaga jarak minimal 1 meter, menghindari kerumunan (KMK No. HK.01.07-MENKES-382-2020 Tentang Protokol Kesehatan Bagi Masyarakat Di Tempat Dan Fasilitas Umum Dalam Rangka Pencegahan COVID-19, 2020; Peraturan Walikota (PERWALI) Tentang Pedoman Pencegahan Dan Pengendalian Corona Virus Disease-19 Pada Masa Tatanan Normal Baru Di Kota Yogyakarta, 2020). Selain penggunaan media mainstream, sosialisasi dalam bentuk pesan bergambar juga giat dilakukan oleh kementrian kesehatan (Yogyakarta Tanggap COVID-19, n.d.).

Gerakan Masyarakat untuk berpola hidup sehat seketika memiliki pendorong kuat untuk dilaksanakan secara masif. Cuci tangan yang sebelumnya masih menjadi kegiatan yang sukarela mau tidak mau menjadi hal yang mesti dilakukan. Dalam protokol kesehatan yang terus digemakan, mencuci tangan masuk dalam salah satu hal yang dihasung. Kantor Kelurahan Sorosutan sebagai salah satu tempat yang memberikan layanan publik kepada masyarakat yang terkait pemerintahan, perekonomian, Pembangunan, Pemberdayaan Masyarakat dan Ketentraman dan Ketertiban tentu niscaya untuk menerima kunjungan dari masyarakat yang memerlukan layanan-layanan tersebut. Oleh karenanya tentu sebelum masyarakat memasuki kantor kelurahan, mereka mesti melakukan protokol Kesehatan, salah satunya mencuci tangan. Keberadaan wastafel yang ada masih dirasakan belum maksimal memberikan layanan karena terkadang masyarakat datang secara bersamaan sehingga memerlukan waktu tambahan untuk mengantri sebelum mencuci tangan. Selain itu, pengunjung harus melakukan pengukuran suhu oleh petugas yang dapat menyebabkan antrian semakin panjang. Meskipun himbauan dan arahan untuk menjaga protokol kesehatan tersebut telah sering disosialisasikan, rendahnya kesadaran warga mengharuskan menempatkan petugas untuk membantu mengingatkan warga sebelum memasuki kantor tersebut. Alat berupa smart wastafel juga masih sangat jarang ditemukan di pasaran karena pada umumnya berupa wastafel yang sederhana. Wastafel otomatis yang sudah pernah dikembangkan sebelumnya seperti pada (Arifin \& Sulistiyowati, 2021) dan (Prasetyo et al., 2021) belum mampu memiliki fitur pengukur suhu dan pengingat pengunjung sehingga keberadaan smart wastafel yang diusulkan sangat diperlukan. Selain manfaat secara teknologi, penelitian ini juga dapat memberikan manfaat secara ekonomi untuk pemberdayaan masyarakat dalam usaha pengembangan produk smart wastafel ini.

\section{METODE PENELITIAN}

Penelitian ini bertujuan menyediakan alat berupa smart wastafel yang dapat membantu mempercepat salah satu proses $4 \mathrm{M}$ yakni mencuci tangan tanpa harus menyentuh peralatan seperti kran, tempat sabun atau peralatan lainnya. Penelitian ini difokuskan Selain sebagai tempat cuci tangan sebagaimana wastafel pada umumnya, wastafel ini memiliki fitur untuk mendeteksi kedatangan pengunjung dan sekaligus mengingatkan pengunjung agar mencuci tangan. Terdapat sensor yang ditempatkan secara khusus di kran air dan tempat sabun sehingga air dan sabun akan keluar secara otomatis. Dengan adanya sensor suhu, pengukuran suhu juga dapat dilakukan di wastafel tersebut.

Otomasisasi pada smart wastafel dengan fitur-fitur yang ada diharapkan dapat meningkatkan kesadaran warga (pengunjung) untuk mencuci tangan dan mengukur suhu guna meminimalkan penyebaran COVID-19 karena rendahnya kesadaran warga terhadap hal ini. Selain itu, kehadiran smart wastafel diharapkan dapat meningkatkan efisiensi dalam proses pencegahan penyebaran COVID-19 terhadap pengunjung kantor kelurahan Sorosutan. Penelitian untuk menyelesaikan permasalahan yang ada di tempat mitra diterapkan dengan tahapan pada Gambar 1. 


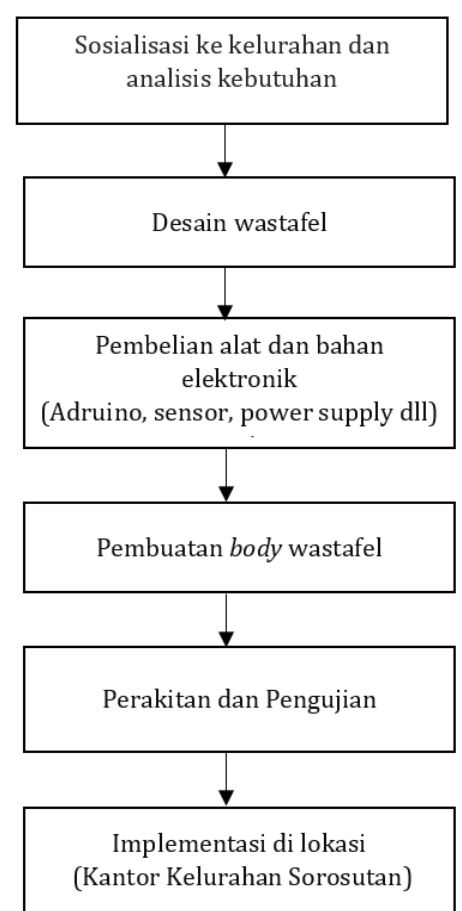

Gambar 1. Tahapan penyelesaian permasalahan

Tahapan pelaksanaan penelitian pada Gambar 1 dapat dijelaskan sebagai berikut:

\section{Sosialisasi ke Kelurahan Sorosutan dan analisis kebutuhan}

Kegiatan ini dilakukan untuk memberikan penjelasan kepada kepala kelurahan terkait alat yang akan dibuat, pengerjaan, spesifikasi, dan rencana pemasangan.

\section{Desain wastafel}

Desain secara umum yang menunjukkan berbagai fitur smart wastafel ditunjukkan pada Gambar 2. Wastafel ini memiliki kemampuan deteksi kedatangan pengunjung, deteksi suhu sekaligus menampilkannya secara langsung. Kran air dan dispenser sabun bekerja secara otomatis. Fiksasi desain dilakukan pada tahap ini untuk selanjutnya dibuat model sesungguhnya.

3. Pembelian alat dan bahan elektronik

Belanja alat dan bahan berupa komponen elektronik yang diperlukan seperti sensor ultrasonik, proximity, sensor suhu, Arduino Nano, power supply, kabel dan beberapa komponen pendukung.

4. Pembuatan body wastafel

Wastafel yang ditunjukkan pada Gambar 2 tersebut dibuat dari bahan fiber glass yang ringan dan kuat.

5. Perakitan dan pengujian

Perakitan komponen elektronika dan pengujian di laboratorium teknik Elektro Universitas Islam Indonesia. Pengujian alat yang meliputi pengujian semua sensor-sensor yang terpasang. Pengujian dilakukan secara berulang-ulang untuk mengetahui kinerja alat dan memastikan alat tersebut dapat bekerja normal dan optimal. Selain itu, pengujian otomasisasi kran air dan dispenser sabun juga dilakukan.

\section{Implementasi di kantor Kelurahan Sorosutan}




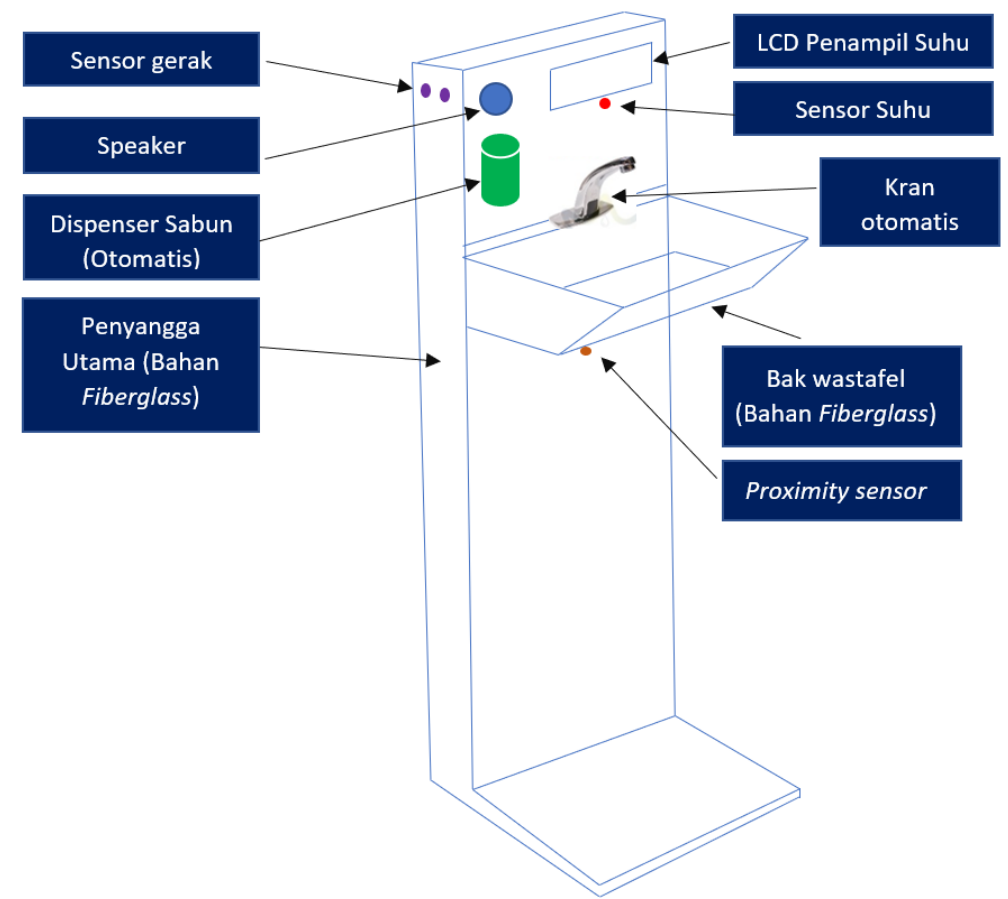

Gambar 2. Berbagai fitur smart wastafel

Detail ukuran wastafel pada Gambar 2 ditunjukkan oleh Gambar 3.

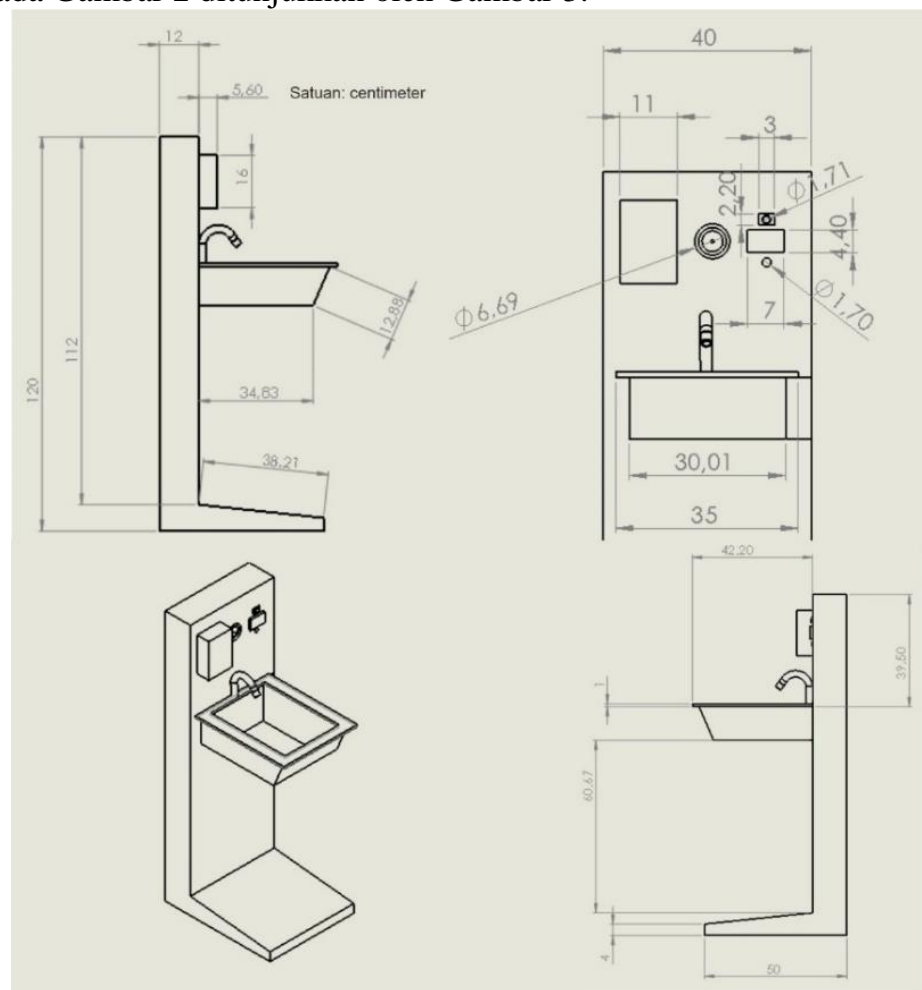

Gambar 3. Detail ukuran fitur smart wastafel

Pemasangan wastafel di kantor Kelurahan Sorosutan, Umbulharjo, Daerah Istimewa Yogyakarta. Selain melibatkan tim peneliti, pemasangan wastafel melibatkan karyawan di kantor Kelurahan Sorosutan. Pengambilan video tentang tata cara penggunaan wastafel tersebut juga akan dilakukan pada bagian terakhir ini. Komponen elektronika yang diperlukan untuk membangun wastafel seperti yang ditunjukkan pada Gambar 3 diperlihatkan dalam Tabel 1. 
Tabel 1. Daftar komponen elektronika utama untuk smart wastafel

\begin{tabular}{lc}
\hline \multicolumn{1}{c}{ Nama komponen } & Jumlah \\
\hline Sensor Ultrasonic HC SR04 & 2 \\
E18-D80NK Infrared & 1 \\
Proximity Sensor & \\
GY-906 MLX90614 Infrared & 1 \\
non contact thermometer & \\
temperature sensor & \\
LCD Graphic 128x64 Blue & 1 \\
White + I2C Module & \\
Arduino Nano & \\
Power Supply 12V 5A & 1 \\
Modul SD Card Player Sound & 1 \\
Speaker USB & 1 \\
\hline
\end{tabular}

\section{HASIL DAN PEMBAHASAN}

Wastafel memiliki beberapa fitur seperti pendeteksi kedatangan, pengukur suhu, dan pengendali keluaran berupa air dan sabun secara otomatis. Selain itu, fitur pengingat dan pemberian informasi kepada pengunjung berupa ucapan selamat datang dan pengingat untuk mencuci tangan berikut tata caranya juga menjadi salah satu kelebihan wastafel ini dibandingkan dengan wastafel yang sudah ada sebelumnnya. Rangkaian elektronika smart wastafel ditunjukkan oleh Gambar 4.

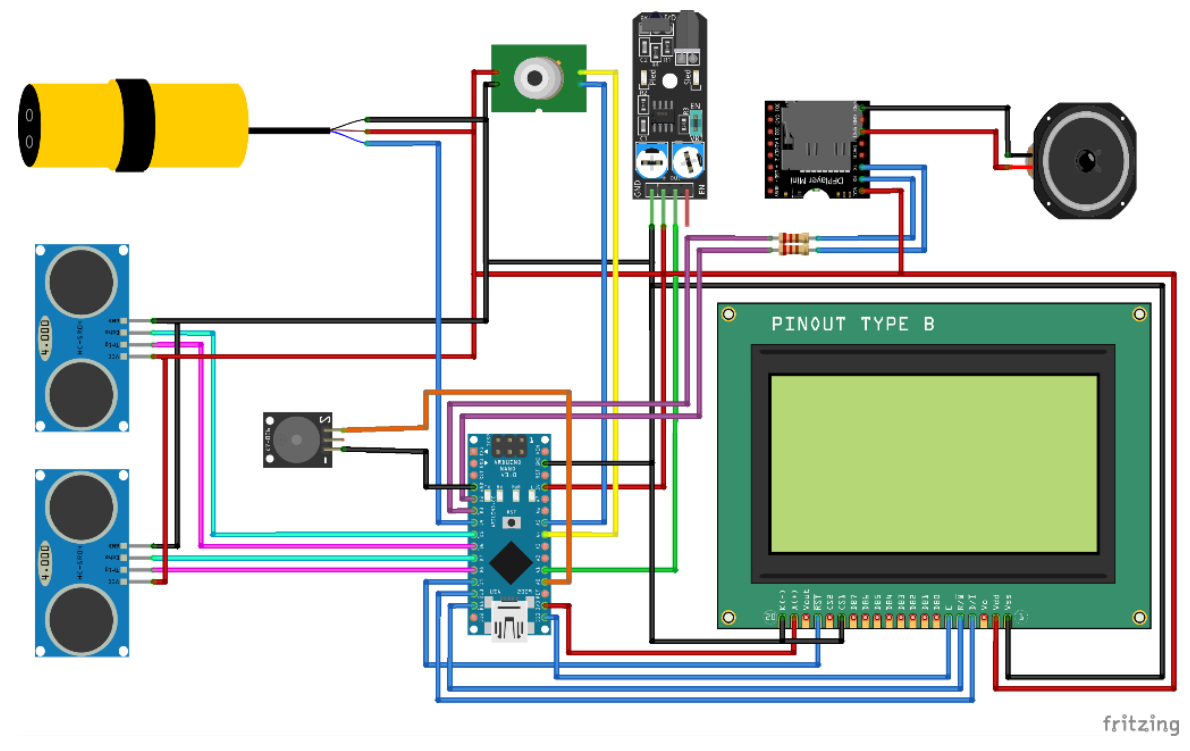

Gambar 4. Desain rangkaian elektronika smart wastafel

Terdapat file rekaman suara yang akan diputar oleh ketika sensor Ultrasonic HC SR04 dan Sensor Proximity aktif. Ketika pengunjung datang, sensor ultrasonic aktif dan memberikan trigger untuk memutar rekaman

\section{"SELAMAT DATANG DI KANTOR KELURAHAN SOROSUTAN, SILAKAN MENCUCI TANGAN TERLEBIH DAHULU”}

Selanjutnya, setelah pengunjung mencuci tangan, sensor proximity yang terpasang di bawah bak wastafel akan aktif dan menjadi trigger untuk memutar rekaman 


\author{
"SILAKAN CEK SUHU ANDA \\ SILAKAN CUCI TANGAN ANDA \\ SAAT MENCUCI TANGAN PASTIKAN ANDA SUDAH MENGGOSOK TELAPAK TANGAN ANDA \\ PASTIKAN ANDA SUDAH MENGGOSOK PUNGGUNG TANGAN ANDA \\ PASTIKAN ANDA SUDAH MENGGOSOK SELA-SELA JARI ANDA \\ PASTIKAN ANDA SUDAH MENGGOSOK UJUNG-UJUNG JARI ANDA \\ PASTIKAN ANDA SUDAH MENGGOSOK PERGELANGAN TANGAN ANDA \\ TERIMA KASIH SUDAH MENCUCI TANGAN \\ SELALU PATUHI PROTOKOL $4 M$ : \\ MEMAKAI MASKER, MENCUCI TANGAN, MENJAGA JARAK, DAN MENJAUHI KERUMUNAN \\ TERIMA KASIH"
}

Hasil rancangan dan implementasi wastafel ditunjukkan oleh Gambar 5.

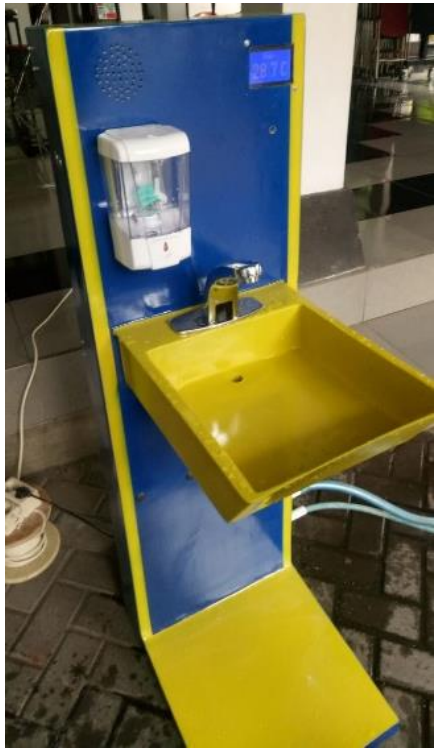

(a)

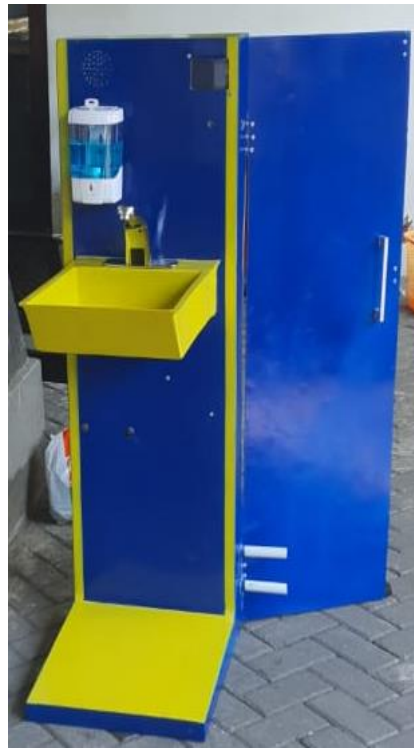

(b)

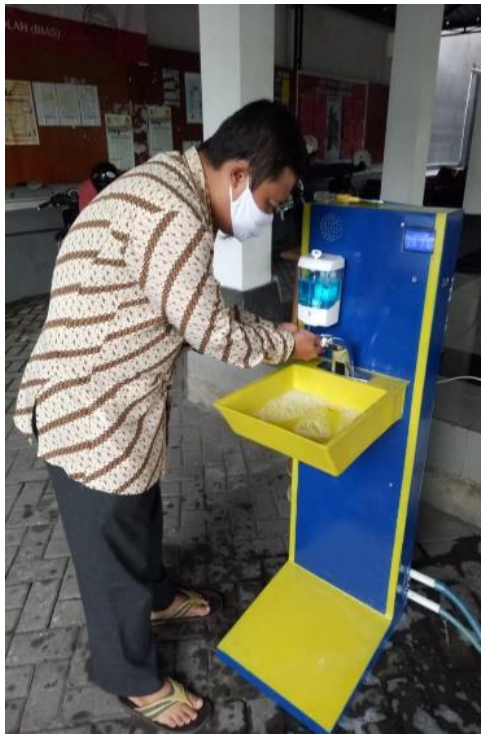

(c)

Gambar 5. Tampilan smart wastafel (a) tampak depan, (b) tampak depan beserta penutup, (c) pengujian wastafel di Kantor Kelurahan Sorosutan oleh Lurah

Dalam pengujian yang dilakukan di Kantor Kelurahan Sorosutan, seluruh sensor dapat bekerja dengan baik. Wastafel dapat mendeteksi kedatangan pengunjung dan memberikan respon suara sesuai dengan desain.

\title{
4. KESIMPULAN
}

Penyebaran virus Covid-19 dapat diminimalisasi dengan meningkatkan kesadaran masyarakat terhadap pentingnya penerapan protokol kesehatan terutama di tempat pelayanan umum seperti kantor Kelurahan Sorosutan, Umbulharjo, Daerah Istimewa Yogyakarta. Smart wastafel hadir sebagai sarana untuk mengurangi penyebaran virus dari para pengunjung kantor kelurahan tersebut. Wastafel bekerja tanpa memerlukan sentuhan manual sebagaimana wastafel pada umumnya sehingga potensi penularan virus dari sarana fisik wastafel dapat dihindari. Selain itu, fitur pengingat pengunjung dan penyadaran terhadap tata cara mencuci tangan yang benar serta kepatuhan terhadap protokol $4 \mathrm{M}$ juga dapat membantu pengunjung untuk selalu waspada di tempat-tempat umum seperti kantor pelayanan publik. Dengan demikian, penularan Covid-19 dalam proses pelayanan umum di kantor kelurahan dapat dicegah.

\section{UCAPAN TERIMA KASIH}

Penulis mengucapkan terima kasih kepada Direktorat Penelitian dan Pengabdian Masyarakat (DPPM) Universitas Islam Indonesia atas dukungan dana yang telah diberikan dalam kegiatan penelitian dan pengabdian kepada masyarakat. 


\section{DAFTAR PUSTAKA}

Arifin, Z., \& Sulistiyowati, I. (2021). Automatic Wastafel Touchless With Solar Cell as Alternative Energy Sources. Procedia of Engineering and Life Science, 1(1), 8

Badan Pusat Statistik Kota Yogyakarta. (2017). Kecamatan Umbulharjo dalam Angka, Umbulharjo Subdistrict in Figures 2017 (II). BPS Kota Kota Yogyakarta

KMK No. HK.01.07-MENKES-382-2020 tentang Protokol Kesehatan Bagi Masyarakat di Tempat dan Fasilitas Umum Dalam Rangka Pencegahan COVID-19. (2020). Kementrian Kesehatan RI. https://promkes.kemkes.go.id/kmk-no-hk0107-menkes-382-2020-tentang-protokol-kesehatan-bagimasyarakat-di-tempat-dan-fasilitas-umum-dalam-rangka-pencegahan-covid19

Peraturan Walikota (PERWALI) tentang Pedoman Pencegahan dan Pengendalian Corona Virus Disease-19 Pada Masa Tatanan Normal Baru di Kota Yogyakarta. (2020). Kota Yogyakarta. https://peraturan.bpk.go.id/Home/Details/148037/perwali-kota-yogyakarta-no-51-tahun-2020

Prasetyo, H., Rofi'i, M., Kurniasari, S., \& Wisnu, M. (2021). Design and Build of Automatic Wastafel Using Ultrasound HC-SR04 Sensor Based on Arduino. Jurnal Neutrino, 13, 7

Yogyakarta Tanggap COVID-19. (n.d.). Retrieved June 28, 2021, from https://corona.jogjaprov.go.id/data-statistik 